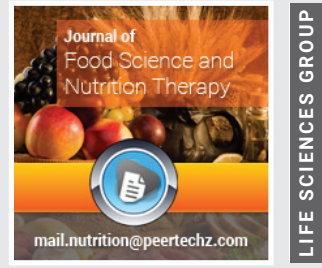

\title{
Evaluation of balanced
}

\section{fertilizer types on yield}

and yield components of

sorghum and validation of soil

fertility map based fertilizer

recommendation

\section{Robe Elema Wako* and Ibsa Aliyi Usmane}

Oromia Agricultural Research Institute, Fedis Agricultural Research Centre, P.O. Box 904, Harar, Ethiopia

\begin{abstract}
Sorghum has tremendous uses for the Ethiopian farmer and no part of this plant is ignored. However, the productivity of sorghum is low. In Harari region, the average productivity of 22.22 Quintal ha- ${ }^{-1}$ which is even below the national average yield of 27.26 Quintal ha-1 mainly constrained by soil nutrient deficiencies. Soil fertility depletion in agricultural land is the fundamental biophysical root cause of declining per capita food production. So balanced fertilizer amended with enough amount of Nitrogen and phosphorous on sorghum gave the highest yield, nutritional content and economic return. Soil fertility map of Ethiopia was conducted during 2016 by ATA (Agricultural transformation Agency).So this fertility map should be validated. Therefore, a field experiment was conducted during 2018 and 2019 main cropping season at Kile PA, Sofi woreda of Harari Regional state under rain-fed condition on balanced fertilizer types. The objectives of the experiment was to evaluate sorghum crop response to different balanced fertilizer types and validate soil fertility map based fertilizer recommendation. And to identify effects of different balanced fertilizer on yield and yield components of sorghum crop. The experiment was laid out in randomized complete block design with three replications. The treatments of this experiment were: control without any fertilizer (no fertilizer applied), NPS, NPSB, NPSZn, NPSZnB, DAP and Urea. The result shows significant difference among the treatments $(P<0.05)$. Analysis of variance was performed using the GLM procedure of SAS Statistical Software Version 9.1.And partial budget analysis was conducted based on CIMMYT procedure [1]. Out of five balanced fertilizer types applied, NPSzn balanced fertilizer type shows the highest significant difference $(P<0.05)$. The highest result of both sorghum grain yield and yield components was obtained from treatments that receive NPSzn fertilizer (52qu/ha) and the lowest grain and biomass yield was obtained from control with no fertilizer (25.48quntal/ha) followed by DAP and urea. Next to grain yield, biomass yield of sorghum is very important parameter that should be considered for the sake of animal feed in the Harari region (kile PA). So, the treatments that receive NPSZn balanced fertilizer shows the highest biomass yield (11.666t/ha). Thus why NPSZn fertilizer is valid for kile PA. Partial budget analysis was conducted and treatments with NPSZn balanced fertilizer was economically profitable for farmers. Mean that, farmers can obtain 39,134 Ethiopian birr/ha by applying NPSZn balanced fertilizer, over the control (with no fertilizer) 17186 Ethiopian birr/ha and the rest treatments.
\end{abstract}

\section{Introduction}

Sorghum (sorghum bicolor 1.) belonging to the family panacea, it is produced in many countries of the world and the fifth major cereal crop in the world in terms of tonnage after maize, wheat, rice and barley [2]. It is the third most important cereal crop in Ethiopia and forth in southern region in terms of area of production [3]. In Ethiopia, it is adapted to a wide range of environments, and hence can be produced in the high lands, medium altitude and low lands. Sorghum is widely produced more than any other crops in the areas where there is moisture stress [4]. It is a staple food crop on which the lives of millions of poor Ethiopians depend. It has tremendous uses for the Ethiopian farmer and no part of this plant is ignored [5]. Sorghum is used in various ways in our country; the grain is used for human foods such as injera, bread, porridge, nifro, infant food, syrup, and local beverage known as "tella" and "arekie." And also, the leaf and stalk are used for animal feed, 
and further, the stalks are used for the construction of houses and fences and as fuel-wood.

However, the productivity(both grain and biomass yield) of sorghum is low; in Harari region, the average productivity of 22.22 quintal ha ${ }^{-1}$ which is even below the national average yield and productivity of 27.26 quintal ha ${ }^{-1}[2,6]$. Soil fertility decline is the main issue in African agriculture in general and in Ethiopia in particular. In Ethiopia, large number of population is hardly satisfied by reliable production, instead a decline in their crop yield is letting them to suffer from poverty and malnutrition. Studies indicated that in some parts of Ethiopia farmer suffer from lack of what to eat particularly in months starting from June up to September (Abera, 2003). Ethiopian soils have been subjected to severe degradation caused by natural and man-made factors [7]. Low soil fertility and shortage of moisture is the major constraints in the reduction of growth and productivity of sorghum [8]. The rate of soil fertility decline depends on soil erosion, nutrient removal in harvests, the rate at which nutrients are returned to the soil through the use of both inorganic fertilizer and organic manures, and the rate of mineralization of soil mineral and organic matter nutrients [9].

Since its start in the early 1970's, fertilizer uses in Ethiopia has focused mainly on the use and application of nitrogen and phosphorous fertilizers in the form of urea and dap for almost all crops. Such unbalanced (phosphorus and urea alone, even though the soil may require micro nutrients like boron, zink etc.) Application of plant nutrients may aggravate the depletion of other important nutrient elements in soils (Fayera, et al. 2014). The appropriate use of nitrogen and phosphorous fertilizer for sorghum production could make an important contribution to optimize profit through increasing production and productivity of sorghum in areas, where there is low practice of using improved technologies such as optimum level of fertilizer [10]. Not only phosphorus and nitrogen in form of dap and urea, application of potassium, sulfur and zinc in different parts of the country sharply increase yield which leads the country started using fertilizers which can supply the deficient nutrients and will continue to use in the form of blends /balanced [6].

Application of balanced fertilizer based on the actual limitation of nutrients in the soil is very crucial to increase production and productivity of crops. Balanced fertilizer amended with enough amount of nitrogen and phosphorous on sorghum gave the highest yield, nutritional content and economic return [11]. Moreover, application of macronutrients in combination with micronutrient increased sorghum yield and concomitantly improved $\mathrm{n}, \mathrm{p}$ and $\mathrm{k}$ uptake and its nutrient use efficiency of sorghum varieties [12]. Now a day, Agricultural Transformation Agency (ATA), has been conducted soil fertility survey and display it on the map. And also recommend different balanced fertilizer based on their map which is blanket recommendation. Thus why, those balanced fertilizer has to be checked and validated before going for calibration. And also, increasing yields through the application of nitrogen and phosphorus alone can deplete other nutrients.
Therefore, information on production practices to optimize the grain yield and quality of sorghum by applying the appropriate type of balanced fertilizer is important to sorghum production in Ethiopia in general and Kile kebele specifically. Hence. The objective of this study was to evaluate the effects of different balanced fertilizers in smallholder sorghum crop based farming systems in Sofi district, kile kebele of Harar regional state. Hence. The objective of this study was to evaluate the effects of balanced fertilizers and application rate in smallholder sorghum crop based farming systems in Kile kebele, Harari regional state.

\section{Objective}

* To evaluate sorghum crop response to balanced fertilizer and validate soil fertility map based fertilizer recommendation.

* To identify effects of different balanced fertilizer on yield and yield components of sorghum crop.

\section{Material and methods}

The study was conducted during 2018 and 2019 main cropping season in Kile kebele Sofi woreda of Harari Regional state. Soil of study area was sandy clay loam. The annual average rainfall of the woreda ranges between to $\mathrm{mm}$. The minimum and maximum annual temperature of 26 and $20^{\circ} \mathrm{C}>$ respectively. Rainfall of the woreda is bimodal, small rains start in March to April interrupted by drought whereas; the second rain starts at July and ends at October with very big variations in distributions and amount. The study area has diversity of climate, soil, and land forms. The topography of the woreda includes mountains, hills, uplands and lowland plains. The altitude ranges 1200 - 1300 meter above sea level.

\section{Experimental design and treatments}

The experiment was laid out in Randomized Complete Block Design (RCBD) with three replication of each treatment. There was three block in the experimental field .Totally there were 18 plots occupied by six treatments, since each treatment was replicated three times.. The space between block was $1.5 \mathrm{~m}$ and space between plots was $0.5 \mathrm{~m}$.The experimental site was ploughed and harrowed before sowing. The improved and moisture stress resistant Melkam sorghum variety was used for the experiment. Plot size was $3 \mathrm{~m} \times 4 \mathrm{~m}$. Furrow rows were made manually in spacing of $75 \mathrm{~cm}$ apart and sorghum seed was drilled manually and thinned by $20 \mathrm{~cm}$ spacing between plants. Those fertilizer treatments was differ in their nutrient composition. For example NPS differ from NPSzn by their nutrient composition (chemical formula), NPS consists, Nitrogen, phosphorous and sulfur in one pack (19 N - 38 P2O5 $+7 \mathrm{~S})$ and NPSzn $(17.7 \mathrm{~N}-35.3 \mathrm{P} 2 \mathrm{O} 5+6.5 \mathrm{~S}+2.5 \mathrm{Zn})$ contains, Nitrogen, phosphorous, sulfur and Zink nutrients in one pack and NPSB (18. $1 \mathrm{~N}-36.1 \mathrm{P} 2 \mathrm{O} 5+6.7 \mathrm{~S}+0.71 \mathrm{~B})$.

\section{The experiment consisting of six treatments}

\section{Treatments:}

T1- control (no fertilizer) 
$\mathrm{T}_{2}, 100 \mathrm{~kg} / \mathrm{ha}$ NPS

$\mathrm{T}_{3}, 100 \mathrm{~kg} / \mathrm{ha}$ NPSB

$\mathrm{T}_{4} 100 \mathrm{~kg} / \mathrm{ha}$ NPSZn

$\mathrm{T}_{5} 100 \mathrm{~kg} / \mathrm{ha}$ NPSZn B

T6 $100 \mathrm{~kg} / \mathrm{ha}$ DAP \& $60 \mathrm{~kg} / \mathrm{ha}$ Urea.

\section{Data collection and soil sampling}

Treatment effects were determined by collecting plant height, panicle length, panicle diameter above ground biomass, and grain yield datas. Plant height was measured using meter tape (since malkam sorghum variety was short in height and simple to measure plant height, it was low land variety. Composite soil sample was collected from $(0-20 \mathrm{~cm})$ depth by diagonal rule or zigzag method with the sampling depth of $(0-20) \mathrm{cm}$, Soil sample after harvest were collected from every plot (from 5 spots /auger points) and analyzed for soil physicochemical properties.

\section{Data analysis}

Analysis of variance was performed using the GLM procedure of SAS Statistical Software Version 9.1. Means were separated using Least Significant Difference (LSD) test. Response variable variables were, gain yield, biomass yield, panicle length and panicle diameter.

\section{Economic analysis for balanced fertilizer}

The dominance analysis procedure, which was used to select potentially profitable treatments, a dominance analysis is thus carried out by first listing the treatments in order of increasing costs that vary. Any treatment that has net benefits that are less than or equal to those of a treatment with lower costs that vary is dominated. The selected treatments by using this technique were referred to as dominated treatments. For each pair of ranked un dominated treatments, a percentage marginal rate of return (\% MRR) was calculated. The percent MRR between any pair of dominated treatments denoted the return per unit of investment in crop management practices expressed as percentage. The MRR (\%) was calculated as follows [1]. For a treatment to be considered a worthwhile option to farmers, the marginal rate of return (MRR) needed to be at least $100 \%$. Thus, the minimum acceptable rate of return was considered to be $100 \%$.Partial budget analysis was used for economic balanced fertilizer analysis by considering the general relationship between the types of balanced fertilizer and sorghum yield per hectare of land. Total revenue, total variable cost, total fixed cost, total cost, net income and benefit cost ratio, of each treatment were analyzed by partial budget analysis based on CIMMYT procedure [1]. The data used for economic analysis were fixed cost and variable cost.

Assessment was undertaken to take the price of sorghum at local market. Based on the assessment done $1 \mathrm{~kg}$ of sorghum was 11ETB at time at field level. For calculation of labour cost the price of human labor was 75ETB at the field. Net income (NI) in ETB/ha, generated from sorghum crop, was computed by subtracting the total cost (TC) in ETB/ha from the total return (TR) in ETB/ha obtained from sorghum sale (Kuboja and Temu, 2013).

\section{$\mathrm{NI}=\mathrm{TR}-\mathrm{TVC}$}

TC is the sum of FC and VC. Fixed costs (FC) are those that do not vary between fertilizer treatments, i.e. sorghum seeds, fertilizer, land rent and. Variable costs, on the other hand, are those that do vary between fertilizer treatments, i.e. fertilizer and labor. Benefit cost ratio (BCR) of each treatment was computed as the ratio of NI earned to the TC expended.

$\mathrm{BCR}=\mathrm{NI} / \mathrm{TC}$

\section{Result and discussion}

\section{Soil analysis}

The textural class of the experimental soil was found to be sandy clay loam with the $\mathrm{pH}$ of $6.83-7.46$, which is slightly alkaline and it is a preferred range for most crops (Table 1). Total nitrogen content was $0.045-0.078 \%$, which is within the range of very low levels $(0.02-0.5 \%)$ for tropical soils. The organic matter content of the soil was $1.68-2.62 \%$, which is within a range of low (0.5-2\%) for Ethiopian soils as per criteria developed by Murphy (1968) [13]. The available P content of the experimental soil was 2.39-3.39ppm that lies in a range of deficiency $(<20-40 \mathrm{mg} / \mathrm{kg}$ ) for most crops (Landon, 1991). And available $\mathrm{K}$ (ppm) was very limiting when compared to the standard [13].

Table 1: Physico-chemical soil properties of the study area.

\begin{tabular}{|c|c|c|c|c|c|c|c|c|c|c|}
\hline \multirow[b]{2}{*}{$\begin{array}{c}\text { Lab } \\
\text { result }\end{array}$} & \multirow[b]{2}{*}{$\begin{array}{l}\text { TN } \\
(\%)\end{array}$} & \multirow[b]{2}{*}{$\begin{array}{l}\text { OM } \\
(\%)\end{array}$} & \multirow[b]{2}{*}{ PH } & \multirow[b]{2}{*}{$\begin{array}{c}\text { Av. } \\
\text { P(ppm) }\end{array}$} & \multirow[b]{2}{*}{$\begin{array}{c}\text { Av. } \\
\text { K(ppm) }\end{array}$} & \multirow[b]{2}{*}{$\mathrm{Na}$} & \multicolumn{4}{|c|}{ Particle distribution (\%) } \\
\hline & & & & & & & Sand & silt & clay & $\begin{array}{c}\text { Textural } \\
\text { class }\end{array}$ \\
\hline Before & 0.045 & 1.68 & 7.46 & 2.39 & 1.008 & 0.219 & 36 & 46 & 18 & \\
\hline After & 0.078 & 2.62 & 6.83 & 3.39 & 0.976 & 0.483 & & Sanc & clá & loam \\
\hline
\end{tabular}

Key*TN: Total Nitrogen; OM: Organic Matter; $\mathrm{PH}: \mathrm{pH}\left(\mathrm{H}_{2} \mathrm{O}\right)$ 1: $2.5 \mathrm{~g}$ soil, Avp Available Phosphorus Ppm, Av.K= Available potassium in ppm and $\mathrm{Na}$ : Sodium

\section{Plant height}

Statistically there was highly significant difference among the treatment at 5\%. Level of confidence. The highest plant height $(156.6 \mathrm{~cm})$ was recorded from treatment which receives $100 \mathrm{kgha}^{-1}$ of NPSzn, but this was in statistical parity with rest treatments except control treatment. and the lowest plant height $(147 \mathrm{~cm})$ was measured from the control treatment. This is because of soil macro and micro nutrients deficiency at kile PA's. Especially Zink and sulfur were the most deficient nutrients there. This finding is in agreement with the report of Gebrekirkos, et al. [11], that plant height increases with increment of fertilizer application from nil to balanced fertilizer type including NPSzn. Furthermore, Redai, et al. 2018 [12] reported that application of NPSzn gives the highest plant height over the absolute control treatment. In addition to this, it can be suggested the application of optimum fertilizer nutrients increased the plant growth and biomass and the increased amounts of nutrient increases the production of sorghum [14]. 


\section{Panicle length (kg/ha)}

The longest panicle length $(30.33 \mathrm{~cm})$ was recorded from treatment that receives $120 \mathrm{Kg} \mathrm{ha}{ }^{-1}$ NPSzn, but this was in statistical parity with the rest treatment except control while the lowest panicle length $(27 \mathrm{~cm})$ was recorded from the control treatment. The result was in conformity with the finding reported that tallest panicle length was recorded from the plot treated by blend fertilizer and the shortest panicle length was recorded from the control [12]. The current result was agree with increasing trend in blended fertilizer and amended with $\mathrm{N}$ and $\mathrm{P}$ in case of (NPSZn) fertilizer shows a corresponding increment of panicle length as compared with the nil fertilizers [11]. The current finding was disagree with finding reported that panicle length of sorghum did not give significantly different response under fertilized and unfertilized conditions [15].

\section{Biomass (kg/ha)}

Biomass yield is an important output as farmers are also interested in it for animal feed and use as fuel wood in addition to grain yield. The highest above ground biomass (11666 $\mathrm{kgha}^{-1}$ ) was recorded from the treatment that receives $100 \mathrm{kgha}^{-1}$ NPSZn and followed by NPSZnB; whereas the lowest above ground biomass (6389 $\mathrm{kgha}^{-1}$ ) was measured from treatments which receive $100 \mathrm{kgha}^{-1} \mathrm{NPS}$ this was in statistical parity with control and treatments that receive $100 \mathrm{~kg} / \mathrm{ha}$ DAP and $60 \mathrm{~kg} / \mathrm{ha}$ Urea. The result is in line with the finding of Gebrekorkos, et al. 2017 reported that the highest biomass yield of sorghum was obtained from the application of blended fertilizer amended with NPSZn which was statistically at parity with the application of balanced fertilizer NPSZn. In contrary, the lowest above ground biomass was obtained from the nil fertilizer plots. Similar finding was reported by Berhane, et al. [16] as application of high nitrogen level results in high amount of biomass yield in sorghum. The current finding was agree with the report plots treated by blend fertilizer gives highest biomass yield over the control plot as the lowest biomass yield was obtained [12].

\section{Grain yield (kg/ha)}

The highest grain yield ( $5200 \mathrm{kgha}^{-1}$ ) was recorded from the treatment that receives $100 \mathrm{kgha}^{-1}$ NPSZn followed by NPSZnB. This is because of soil macro and micro nutrients deficiency at kile PA's is compensated by balanced fertilizer. Especially Zn and sulfur were the most deficient nutrients [17]. Whereas the lowest grain yield $\left(2548 \mathrm{kgha}^{-1}\right)$ was measured from control treatment (Table 2). The current finding was agree with finding reported as the plots treated by NPSZn fertilizer gives highest grain yield as that of NPKSZn and the lowest grain yield of sorghum was recorded from control [12]. Similarly, Gebrekorkos, et al. [11] reported that the maximum grain yield was obtained from the balanced fertilizer types NPSZn, while the lowest yield was obtained in unfertilized plots. Additionally, the finding reported that increasing application of fertilizer nutrients such as N, P, K and $\mathrm{Zn}$ increases the grain yield and biomass weight of sorghum significantly (Regessa, 2005). Additionally, the result was agreed with the finding reported
Table 2: Yield and Yield Components Of Sorghum As Influenced By Different Balanced Fertilizer Type.

\begin{tabular}{|c|c|c|c|c|c|}
\hline Treatments & $\begin{array}{c}\text { Plant } \\
\text { height(cm) }\end{array}$ & $\begin{array}{c}\text { Panicle } \\
\text { length(cm) }\end{array}$ & $\begin{array}{c}\text { Panicle } \\
\text { diameter }(\mathrm{cm})\end{array}$ & $\begin{array}{c}\text { Biomass } \\
\mathrm{kg} / \mathrm{ha}\end{array}$ & $\begin{array}{c}\text { Yield kg/ } \\
\text { ha }\end{array}$ \\
\hline Control(no fertilizer) & $147^{b}$ & $27^{c}$ & $5.47^{c}$ & $6944^{c}$ & $2548^{c}$ \\
\hline 100 NPS kg/ha & $153.8^{\mathrm{a}}$ & $29.6^{\mathrm{ab}}$ & $6.33^{b}$ & $6389^{c}$ & $3822.2^{\mathrm{abc}}$ \\
\hline 100 NPSB kg/ha & $152.87^{\mathrm{ab}}$ & $29.07^{a b}$ & $6.33^{b}$ & $8750^{\mathrm{abc}}$ & $3844.4^{\mathrm{abc}}$ \\
\hline 100 NPSZn kg/ha & $156.6^{a}$ & $29.73^{a b}$ & $7.27^{\mathrm{a}}$ & $11666^{\mathrm{a}}$ & $5200^{a}$ \\
\hline 100 NPSZnB kg/ha & $155.93^{\mathrm{a}}$ & $30.33^{\mathrm{a}}$ & $6.93^{\mathrm{a}}$ & $10869^{\mathrm{ab}}$ & $4546.2^{\mathrm{ab}}$ \\
\hline $\begin{array}{c}100 \text { DAP + } 60 \text { UREA } \\
\mathrm{kg} / \mathrm{ha}\end{array}$ & $151.8^{\mathrm{ab}}$ & $28.73^{\mathrm{ab}}$ & $6.8^{\mathrm{ab}}$ & $8055 b^{c}$ & $3238.9^{\mathrm{bc}}$ \\
\hline LSD & 6.77 & 1.28 & 0.55 & 3538.5 & 1465.9 \\
\hline CV (\%) & 2.43 & 2.42 & 4.67 & 21.16 & 20.84 \\
\hline
\end{tabular}

Key* PH: Plant Height (cm), PL: Panicle Length (cm); Panicle diameter (cm)

Biomass kg/ha Gy: Grain Yield $\left(\mathrm{kg} \mathrm{ha}^{-1}\right)$; *: H significant at $\mathrm{P}<0.05$

as sorghum yield increase with increase in the rate of nitrogen and application of blended fertilizer to the optimum rate [1821].

\section{Economic analysis}

The economic evaluation and comprising partial budget analysis with dominance, and marginal rate of return was carried out. To estimate economic parameters, the yield of sorghum was valued based on average market price collected from the local markets during two consecutive years of production. The average cost of urea, NPS, NPSB, NPSZn, NPSZnB, and DAP 9.6 and birr per kg respectively. A wage rate of 75 birr a man per day was considered. Some of the concepts used in the partial budget analysis are gross field benefit (GFB), total variable cost (TVC), TFC and the net benefit (NB) [1].

\section{Effect of balanced fertilizer on economic sorghum pro- ductivity}

Data concerning to economic comparison was presented in Table 3. The detail evaluation of the economic analysis of fertilizer treatments was shows that, as a result, the direct impact of balanced fertilizer (NPSZn) in generating NI was very high for a hectare of land per season which means good value from hectare than absolute control. Maximum total cost (7666ETB) was obtained by NPSZnB treatment whereas the minimum variable cost (5746ETB) was obtained by $\mathrm{T} 1$ (control). Benefit cost ratio (BCR) of each treatment was computed as the ratio of NI earned to the TC expended. Accordingly, maximum BCR (5.1) were obtained by $\mathrm{T} 4$ means that treatment which receives NPSZn fertilizer. However, the lower BCR was recorded by $\mathrm{T} 1$ and T8. This implies that even though maximum yield was obtained by those treatments they were economically not more attractive. From this economic analysis the application, T4 (NPSZn)) was the most economically attractive treatment with high BCR and optimum net benefit.

The marginal rate of return above $100 \%$ is high and acceptable to farmers (CIMMYT, 1988).With the acceptable marginal rate of return (MRR), NPSZn application was produced the highest net benefits and marginal rate of return as compared to absolute control and DAP and Urea. Therefore, farmers in the study area were benefited when they apply 
Table 3: Financial analyses for different balanced fertilizers.

\begin{tabular}{|c|c|c|c|c|c|c|c|}
\hline Treatments & $\begin{array}{c}\text { Yield kg/ } \\
\text { ha }\end{array}$ & $\begin{array}{c}\text { TR(ETB/ } \\
\text { ha) }\end{array}$ & $\begin{array}{c}\text { TVC(ETB/ } \\
\text { ha) }\end{array}$ & $\begin{array}{c}\text { TFC(ETB/ } \\
\text { ha) }\end{array}$ & $\begin{array}{c}\text { TC(ETB/ } \\
\text { ha) }\end{array}$ & $\begin{array}{c}\text { NI(ETB/ } \\
\text { ha) }\end{array}$ & B/C \\
\hline $\begin{array}{c}\text { T1,Control(no } \\
\text { fertilizer) }\end{array}$ & 2548 & 22932 & 4246 & 1500 & 5746 & 17186 & 2.9 \\
\hline T2,NPS & 3822.2 & 34399. & 6166 & 1500 & 7666 & 26733 & 3.5 \\
\hline T3,NPSB & 3844.4 & 34599.6 & 6166 & 1500 & 7666 & 26933.6 & 3.5 \\
\hline T4,NPSzn & 5200 & 46800 & 6166 & 1500 & 7666 & 39134 & 5.1 \\
\hline T5,NPSZnB & 4546.2 & 40915.8 & 6166 & 1500 & 7666 & 33249.9 & 4.3 \\
\hline $\begin{array}{c}\text { T6, DAP and } \\
\text { Urea }\end{array}$ & 3238.9 & 29150.1 & 6166 & 1500 & 7666 & 21484.1 & 2.83 \\
\hline
\end{tabular}

KEY* TR: Total Revenue; TVC: Total Variable Cost; TFC: Total Fixed Cost; NI: Net Income and B/C: Benefit Cost ratio

NPSZn rather than absolute control and the experiment with NPSZn and NPSZnB treatments are economically viable.

\section{Conclusion and Recommendation}

The results of the study shows significant difference among the treatments $(p<0.05)$, out of five fertilizer types applied, NPSzn balanced fertilizer type shows the highest significant difference. The highest plant height $(156.6 \mathrm{~cm})$ was recorded from treatment which receives $100 \mathrm{Kgha}^{-1} \mathrm{NPSZn}$. Biomass yield is an important output as farmers are also interested in it for animal feed and use as fuel wood in addition to grain yield. The highest above ground biomass (11666 $\mathrm{kgha}^{-1}$ ) was recorded from the treatment that receives $100 \mathrm{kgha}^{-1} \mathrm{NPSZn}$ and followed by NPSZnB; whereas the lowest above ground biomass (6389 $\mathrm{kgha}^{-1}$ ) was measured from treatments which receive 100 $\mathrm{kgha}^{-1}$ NPS.Therfore, to get the highest, above ground biomass, farmers should apply NPSZn fertilizer. The highest grain yield (5200 $\mathrm{kgha}^{-1}$ ) was recorded from the treatment that receives 100kgha-1 NPSZn followed by NPSZnB.whereas the lowest grain yield ( $2548 \mathrm{kgha}^{-1}$ ) was measured from control treatment (table 2). Using soil test based recommended balanced fertilizer type is economically profitable. The ATA recommendation of NPSZn for kile PA, of Harari regional state is valid for a given specific location.

\section{Recommendation}

Farmers should use fertilizer during the sowing season. Farmers of kile PA, should purchase and use NPSZn balanced fertilizer and urea only. Not only inorganic fertilizer, farmers better to apply organic manures to alleviate their soil from low organic matter and soil salinity. Research extension, Office of agriculture and natural resource and other NGO's should create awareness for farmers on fertilizer application and which balanced fertilizer to be used.

\section{Acknowledgement}

I want to acknowledge AGPII funding organization for their good and timely budget allocation during the life span of the project. And also fadis agricultural research center for they allow us all facility for the research accomplishments. I also acknowledge, Dr Dagnachow lule, project coordinator, for He's strict follow up and advice.

\section{References}

1. CIMMYT (International Maize and Wheat Improvement Center) (1988) From Agronomic Data to Farmer Recommendations: An Economics Training Manual. Completely revised. Link: https://bit.ly/2SrPXFD

2. FAO (Food and Agricultural Organization) (2012) Database of agricultural production FAO Statistical Databases (FAOSTAT).

3. Central Statistics Authority (CSA) (2018) Agricultural sample survey 2017/2018. Report on Area and Production of Major Crops (Private Peasant Holdings, Meher Season). Statistical Bulletin No. 586. Addis Ababa, Ethiopia.

4. MoA (Ministry of Agriculture) (2010) Animal and Plant Health Regulatory Directorate, Crop variety register issue no 13 . Addis Ababa, Ethiopia.

5. Asfaw A (2007) The role of introduced sorghum and millets in Ethiopian agriculture Melkassa Agricultural Research Center, Nazareth, Ethiopia. Sate Journal Journal 3. Link: https://bit.ly/30yL4iu

6. Central Statistics Authority (CSA) (2016) Agricultural sample survey 2015/2016. Report on Area and Production of Major Crops (Private Peasant Holdings, Meher Season). Statistical Bulletin No. 584. Addis Ababa, Ethiopia.

7. IFDC (2015) Assessment of Fertilizer Consumption and Use by Crop in Ethiopia. FUBC Ethiopian Final Report 2015. Link: https://bit.ly/2GpaYhG

8. Gebreyesus BT (2012) Effect of Tillage and Fertilizer Practices on Sorghum Production in Abergelle Area, Northern Ethiopia. Momona Ethiop J Sci 4: 5269. Link: https://bit.ly/34u8jva

9. Kaizzi KC, Mohammed MB, Nouri M (2017) Fertilizer Use Optimization: Principles and Approach. In: Fertilizer Use Optimization in Sub-Saharan Africa. Charles S. Wortmann and Keith Sones (eds). CAB International, Nairobi, Kenya 9-19. Link: https://bit.ly/34qOfKb

10. Hegano A, Adicha A, Tessema S (2016) Economic Analysis of the Effect of Nitrogen and Phosphorous Fertilizer Application for Sorghum Production at Alduba, South Omo, South Western Ethiopia. International Journal of Agricultural Economics 1: 26-30. Link: https://bit.ly/34ljwhE

11. Gebrekorkos G, Egziabher YG, Habtu S (2017) Response of Sorghum (Sorghum bicolor (L.) Moench) varieties to blended fertilizer on yield, yield component and nutritional content under irrigation in Raya valley, Northern Ethiopia. Inter J Agri Biosci 6: 153-162. Link: https://bit.ly/2GI8Scs

12. Weldegebriel R, Araya T, Egziabher YG (2018) Effect of NPK and blended fertilizer application on Yield, Yield Component and its profitability of Sorghum (Sorghum bicolor (L.) Moench) varieties under rainfed condition in north western Tigray, Ethiopia. Int J Life Sciences 6: 60-68. Link: https://bit.ly/36zKHYY

13. Murphy HF (1968) A report on the fertility status and other data on some soils of Ethiopia, Experiment Station Bulletin No. 44, College of Agriculture Dire Dawa, Ethiopia. 551. Link: https://bit.ly/3jzLblj

14. Bayu W, Rethman NFG, Hammes PS, Alemu G (2006) Effects of Farmyard Manure and Inorganic Fertiliz- ers on Sorghum Growth, Yield, and Nitrogen Use in a Semi-Arid Area of Ethiopia. Journal of Plant Nutrition 29: 391- 407. Link: https://bit.ly/3ngyn5D

15. Sibhatu B, Berhe H, Gebrekorkos G, Abera K (2017) Effect of Tied Ridging and Fertilizer on the Productivity of Sorghum (Sorghum bicolor (L.) Moench) at Raya Valley, Northern Ethiopia. Current Agriculture Research Journal 5: 396403. Link: https://bit.ly/2GxvMU1

16. Berhane S, Ketema B, Taye T (2015) Effect of Cowpea Density and Nitrogen Fertilizer on a Sorghum-Cowpea Intercropping System in Kobo, Northern Ethiopia. Inter J Agric Forest 5: 305-317. Link: https://bit.ly/3jCcqM8

17. ATA (Agricultural Transformation Agency) (2016) Soil Fertility Status and Fertilizer Recommendation Atlas of the Southern Nations Nationalities and 
Peoples' Regional State, Ethiopia, by Ministry of Agriculture and Natural Resources and Agricultural Transformation Agency, Ethiopian, Addis Ababa, Ethiopia.

18. Kasaye Abera Meshesha (2018) Effect of Rates and Time of Nitrogen Fertilizer Application on Yield and Yield Components of Sorghum (Sorghum bicolor (L.) Moench) at Raya Valley, Northern Ethiopia. A Thesis Submitted to the School of Plant Sciences Post Graduated Program Directorate Haramaya University, Haramaya, Ethiopia.
19. Northern Ethiopia (2018) Momona Ethiopian Journal of Science (MEJS). 10 140-156. Link: https://bit.ly/3d2IHdK

20. Sanchez PA, Shepherd KD, Soul MJ, Place FM, Buresh RJ, et al. (1997) Soi fertility replenishment in Africa. Replenishing soil fertility Africa, SSSA, Special Publication. SSSA, Madison, USA 51. Link: https://bit.ly/33vXWry

21. Angus JF (2001) Nitrogen supply and demand in Australian agriculture. Australian Journal of Experimental Agriculture 41: 277-288. Link: https://bit.ly/2HNWsQX

\section{Discover a bigger Impact and Visibility of your article publication with}

\section{Peertechz Publications}

\section{Highlights}

* Signatory publisher of ORCID

- Signatory Publisher of DORA (San Francisco Declaration on Research Assessment)

- Articles archived in worlds' renowned service providers such as Portico, CNKI, AGRIS, TDNet, Base (Bielefeld University Library), CrossRef, Scilit, J-Gate etc.

* Journals indexed in ICMJE, SHERPA/ROMEO, Google Scholar etc.

* OAI-PMH (Open Archives Initiative Protocol for Metadata Harvesting)

* Dedicated Editorial Board for every journal

* Accurate and rapid peer-review process

* Increased citations of published articles through promotions

* Reduced timeline for article publication

Submit your articles and experience a new surge in publication services (https://www.peertechz.com/submission).

Peertechz journals wishes everlasting success in your every endeavours.

Copyright: @ 2020 Wako RE, et al. This is an open-access article distributed under the terms of the Creative Commons Attribution License, which permits unrestricted use distribution, and reproduction in any medium, provided the original author and source are credited. 